\title{
Kualitas Audit Berdasarkan Skeptisme Profesional dan Fee Audit (Studi Empiris pada Kantor Akuntan Publik Kota Bandung)
}

\author{
Sheila Swiscindya Atantri', Dani Sopian² \\ Program Studi Akuntansi ${ }^{1,2}$
}

STIE STAN Indonesia Mandiri, Jl. Jakarta No. 79 Bandung ${ }^{1,2}$

Email: sheila.swiss31@gmail.com ${ }^{1}$, sopyan.dani@gmail.com ${ }^{2}$

\begin{abstract}
ABSTRAK
Penelitian ini bertujuan untuk mengetahui kualitas audit berdasarkan skeptisme profesional dan fee audit baik secara simultan maupun secara parsial. Penelitian ini dilakukan pada auditor di Kantor Akutan Publik di kota Bandung. Sampel dalam penelitian ini ialah 51 responden dengan teknik penentuan sampel yang digunakan purposive sampling. Analisis data yang digunakan dalam penelitian ini adalah analisis regresi linear berganda. Hasil penelitian ini menunjukkan secara simultan menunjukkan bahwa skeptisme profesional dan fee audit berpengaruh positif signifikan terhadap kualitas audit, sedangkan secara parsial skeptisme profesional dan fee audit berpengaruh positif signifikan terhadap kualitas audit.
\end{abstract}

Kata Kunci : Skeptisme Profesional, Fee Audit dan Kualitas Audit.

\section{ABSTRACT}

This study aims to determine the effect of professional skepticism and audit fees on audit quality both simultaneously and partially. This research was conducted on auditors at the Public Accounting Office in the city of Bandung. The sample in this study was 51 respondents with a sample determination technique used purposive sampling. Analysis of the data used in this study is multiple regression analysis. The results of this study indicate simultaneously that professional skepticism and audit fees have a significant positive effect on audit quality, while partially professional skepticism and audit fees have a significant positive effect on audit quality.

Keywords : Professional Skepticism, Audit Fee and Audit Quality.

\section{PENDAHULUAN}

Berdasarkan Standar Profesional Publik (SPAP) Audit yang dilaksanakan auditor dapat berkualitas jika memenuhi standar atau ketentuan Auditing. Ketentuan dan standar ini sangat berpengaruh terhadap kualitas audit. Karena pada dasarnya auditor merupakan profesi yang lahir dan besar dari tuntutan publikkan adanya mekanisme komunikasi independen antara entitas ekonomi dengan para stockholder terutama berkaitan dengan akuntabilitas entitas yang bersangkutan. Profesi Akuntan Publik merupakan profesi kepercayaan masyarakat karena profesi inilah masyarakat 
memperoleh informasi keuangan yang andal sebagai dasar pengambilan keputusan baik untuk pihak internal ataupun eksternal. Sehingga Auditor harus melaksanakan tugasnya dengan prinsip-prinsip audit, standar-standar audit yang telah ditetapkan oleh IAI (Ikatan Akuntan Indonesia) agar dapat menghasilkan suatu laporan audit yang berkualitas (Nihestita at al, 2018).

De Angelo (1981) dalam Law Tjun Tjun et al (2012) mendefinisikan kualitas audit sebagai probabilitas dimana seorang Auditor menemukan dan melaporkan tentang adanya suatu pelanggaran dalam sistem akuntansi kliennya. Hasil penelitiannya menunjukkan bahwa KAP yang besar akan berusaha untuk menyajikan kualitas audit yang lebih besar dibandingkan dengan KAP yang kecil. Deis dan Giroux (1992) melakukan penelitian tentang empat hal dianggap mempunyai hubungan dengan kualitas audit yaitu (1) Lama waktu Auditor telah melakukan pemeriksaan terhadap suatu perusahaan (tenure), semakin lama seorang Auditor telah melakukan audit pada klien yang sama maka kualitas audit yang dihasilkan akan semakin rendah, (2) jumlah klien, semakin banyak jumlah klien maka kualitas audit akan semakin baik karena Auditor dengan jumlah klien yang banyak akan berusaha menjaga reputasinya, (3) kesehatan keuangan klien, semakin sehat kondisi keuangan klien maka akan ada kecenderungan klien tersebut untuk menekan Auditor agar tidak lama dalam menjalankan tugasnya.

Skeptisme professional adalah suatu sikap yang mencakup suatu pikiran yang selalu mempertanyakan dan selalu waspada terhadap kodisi yang dapat mengindikasikan adanya kemungkinan salah saji, baik yang disebabkan oleh kecurangan maupun kesalahan, serta meliputi sikap kritis dalam melakukan penilaian melakukan penilaian atas bukti audit. (Hery, 2019 : 64).

Fee audit dapat diartikan sebagai jumlah biaya yang dibebankan kepada klien atas penggunaan jasa auditor yang dimanfaatkan untuk proses audit. Dalam menentukan besaran jumlah imbalan audit, akuntan publik harus memperhatikan hal-hal sebagai berikut: 1.Kebutuhan klien 2.Tugas dan tanggung jawab menurut hukum 3 . Independensi 4. Tingkat kealian dan tanggung jawab yang melekat pada pekerjaan yang dilakukan, serta tingkat kompleksitas pekerjaan 5. Banyaknya waktu yang diperlukan secara efektif digunakan oleh akuntan publik dan stafnya untuk menyelesaikan pekerjaan 6. Basis penetapan fee audit yang disepakati. Fee audit 
diproksikan menggunakan logaritma natural dari $10 \%$ atas akun professional fees pada laporan keuangan ( Nida dan Annisa, 2018)

\section{Pengaruh Skeptisme Profesional terhadap Kualitas Audit}

Skeptisme professional merupakan sikap (attitude) auditor dalam melakukan penugasan audit dimana sikap ini mencakup pikiran yang selalu mempertanyakan dan melakukan evaluasi secara kritis terhadap bukti audit. Seorang auditor (pemeriksa) tidak boleh menganggap bahwa manajemen organisasi diperiksa tidak jujur, tetapi tidak boleh juga menganggap bahwa kejujuran manajrmen tersebut tidak diragukan lagi. Seorang auditor perlu menerapkan sikap skeptisme profesionalnya selama pemeriksaan, untuk mendapat keyakinan yang memadai bahwa salah saji material atau ketidakakuratan yang signifikan dalam data akan terdeteksi, baik karena kesalaha, kecurangan, tindakan, tindakan melanggar hukumatau pelanggaran peraturan. Penerapan skeptisme profesional oleh auditor secara memadai dalam setiap pemeriksaan membawa dampak tercapainya hasil audit yang berkualitas. Jika skeptisme pada auditor maka akan meningkatkan kualitas audit.

\section{Pengaruh Fee Audit terhadap Kualitas Audit}

Fee audit merupakan besarnya imbalan yang diterima oleh auditor yang besar nya tergantung dari bergagai faktor ekdternal maupun internal auditor. Sebelum menentukan besaran fee biasanya auditor dan manager bernegosiasi berapa besar nya yang akan dibayarkan terlebih dahulu. Dengan begitu akan saling menguntungkan dan tidak akan merugikan salah atu belah pihak dan akan terjalin kerja sama yang baik jika mengikuti aturan yang jelas.Penentuan auditor biasanya mengacu pada kontrak antara auditor dan auditee sesuai waktu yang dilaksanakan nya proses audit tersebut. Sebelum mengerjakan audit, auditor dan auditee menentukan fee audit terlebih dahulu. Fee audit berpengaruh terhadap taat kerja auditor jika auditor mendapatkan fee yang sesuai dengan beban tugas nya maka ada pekerjaan yang dikerjkan dengan maksimal. Karena fee audit yang diperoleh auditor dalam satu tahun dan estimasi biaya operasional yang dibutuhkan untuk melaksanakan prosess audit untuk meningkatkan kualitas audit. 
Berdasarkan kerangka teoritis tersebut, dapat dikemukakan model analisis seperti ditunjukan pada berikut ini :

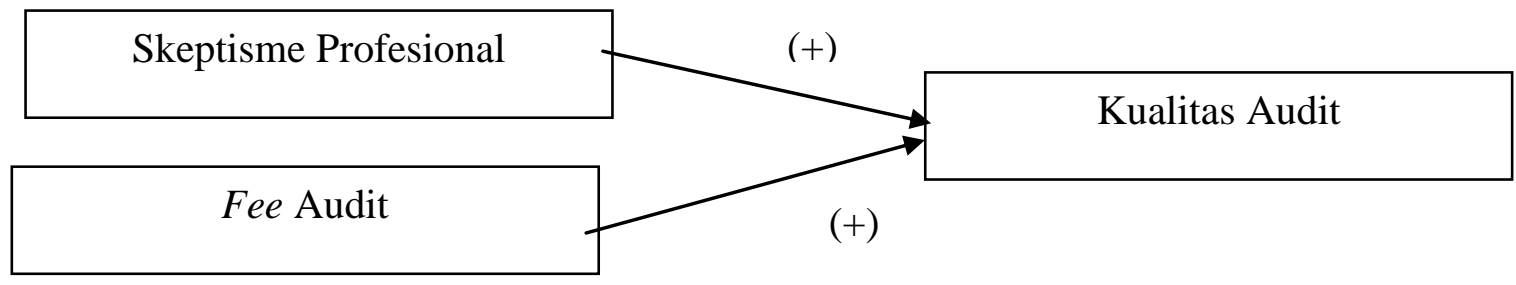

Gambar 1: Model Analisis

Berdasarkan kerangka pemikiran maka hipotesis dalam penelitian ini adalah sebgai berikut :

$\mathrm{H}_{1}$ : Terdapat pengaruh positif dari skeptisme professional terhadap kualitas audit.

$\mathrm{H}_{2}$ : Terdapat pengaruh positif dari fee audit terhadap kualitas audit.

\section{METODE PENELITIAN}

Populasi dalam penelitian ini adalah auditor yang bekerja di Kantor Akuntan Publik kota Bandung.pengambilan sampel diambil secara acak dari tiap sub-sub populasi dengan memperhitungkan besar kecilnya sub-sub populasi tersebut. Sehingga sampel dalam penelitian ini sesuai dengan kuesioner yang kembali yang akan diolah kriteria tersebut ialah :

1. Sampel ,merupakan seorang auditor yang bekerja di Kantor Akuntan Publik kota Bandung.

2. Auditor yang bekerja di Kantor Akuntan Publik kota Bandung dan pernah melakukan audit.

Hipotesis adalah suatu perumusan sementara mengenai suatu hal yang dibuat untuk menjelaskan hal itu dan juga dapat menuntun atau mengarahkan penyelidikan selanjutnya. Jika yang dihipotesis adalah masalah statisti maka hipotesis ini disebut hipotesis statistik. Langka-langkah penyelidikan hipotesis disebut juga dengan pengujian hipotesis (Husein, 2005 :168). Menurut Siregar (2013 : 38) menjelaskan bahwa hipotesis diartikan sebagai jawaban atau dugaan sementara yang harus diuji kebenarannya. Pengujian signifikan hipotesis dapat menggunakan tabel dan juga 
dapat dihitung uji $\mathrm{F}$ ( $F$ test) untuk pengujian secara simultan dan uji $\mathrm{t}(t$ test $)$ untuk pengujian secara parsial.

Pada penelitian ini, peneliti menggunaka analisis regresi linier berganda karena dalam penelitian ini terdapat dua variabel independen dan satu variabel dependen. Dengan bantuan program SPSS (Statistical Packaged for Social Science), adalah persamaan umum regresi linier berganda dengan dua predikor:

$$
Y=a+b_{1} X_{1}+b_{2} X_{2}+\varepsilon
$$

Keterangan :

$\mathrm{Y} \quad=$ Variabel dependen

a = Nilai konstan yaitu nilai $Y$ ketika $X=0$

$b_{1} b_{2}=$ Koefisien regresi atau angka arah yang meunjukan angka peningkatan atau penurunan variabel dependen yang di dasarkan padaperubahan variabel independen. Apabila (+) arah garis naik dan apabila (-) maka arah garis turun.

$X_{1} X_{2}=$ Variabel independen

$\varepsilon \quad=$ Standar error

Berdasarkan pengertian diatas, model persamaan regresi yang digunakan dalam penelitian ini adalah sebagai berikut :

$$
K A=a+b_{1} S P+b_{2} F A+\varepsilon
$$

Keterangan :

KA $=$ Kualitas Audit

a $\quad=$ Nilai konstan

$b_{1} \quad=$ Koefesien regresi X1 (skeptisme professional)

$b_{2} \quad=$ Koefesien regresi X2 (fee audit)

SP $\quad=$ Skeptisme Profesional

$\mathrm{FA} \quad=$ Fee Audit

$\varepsilon \quad=$ Standar error

\section{HASIL DAN PEMBAHASAN}

Penelitian ini menggunakan sampel auditor yang bekerja di Kantor Akuntan Publik kota Bandung dan terdaftar di Institut Akuntan Publik Indonesia. Teknik pengambilan sampel yang digunakan dalam penelitian ini adalah purposive 
sampling. Berdasarkan kriteria yang telah ditetapkan maka diperoleh sebanyak 51 sampel auditor dari 20 KAP di kota Bandung yang selanjutnya akan digunakan sebagai sumber analisis dalam penelitian ini.

\section{Uji signifikan secara simultan (Uji F)}

Pengujian uji f (simultan) ini digunakan untuk melihat apakah variabel dependen mempunyai pengaruh yang bermakna terhadap variabel independen. Hasil pengujian uji $f$ dapat dilihat pada tabel berikut :

Tabel Uji F

ANOVA $^{\mathrm{a}}$

\begin{tabular}{|r|l|r|r|r|r|r|}
\hline \multicolumn{2}{|c|}{ Model } & $\begin{array}{r}\text { Sum of } \\
\text { Squares }\end{array}$ & Off & $\begin{array}{r}\text { Mean } \\
\text { Square }\end{array}$ & F & Sig. \\
\hline \multirow{2}{*}{1} & Regression & 237.230 & 2 & 118.615 & 30.068 & $.000^{\mathrm{b}}$ \\
\cline { 2 - 8 } & Residual & 189.358 & 48 & 3.945 & & \\
\cline { 2 - 8 } & Total & 426.588 & 50 & & & \\
\hline
\end{tabular}

a. Dependent Variabel : KA

b. Predictorsn : (Constant), FA,SP

Bedasarkan tabel diatas dapat disimpulkan bahwa nilai signifikansi 0,000. Sesuai ketentuan uji $\mathrm{F}$ yang telah dijelaskan dipembahasan sebelumnya, maka dapat disimpulkan bahwa hipotesis $\mathrm{H}_{1}$ dapat diterima dan $\mathrm{H}_{0}$ dapat ditolak, maka hipotesis ini menyatakan bahwa skeptisme profesional berpengaruh positif dan signifikan terhadap kualitas audit. $\mathrm{H}_{2}$ dapat diterima dan $\mathrm{H}_{0}$ dapat ditolak, maka hipotesis ini menyatakan bahwa fee audit berpengaruh positif dan signifikan terhadap kualitas audit.

\section{Uji signifikan secara parsial (Uji t)}

Menurut Ghazali (2001 : 44) uji relative t digunakan untuk menunjukan seberapa jauh pengaruh satu variabel independen secara individual dalam menerangkan variasi variabel dependen 
Tabel Uji $\mathbf{t}$

\begin{tabular}{|c|c|c|c|c|c|c|}
\hline & \multirow[t]{2}{*}{ Model } & \multicolumn{2}{|c|}{$\begin{array}{c}\text { Unstandardized } \\
\text { Coefficients }\end{array}$} & \multirow{2}{*}{$\begin{array}{l}\text { Standardized } \\
\text { Coefficients }\end{array}$} & \multirow[t]{2}{*}{$\mathrm{t}$} & \multirow[t]{2}{*}{ Sig } \\
\hline & & B & Std.Error & & & \\
\hline \multirow[t]{3}{*}{1} & (Constant) & 2.993 & 2.643 & & 1.132 & .263 \\
\hline & SP & .491 & .134 & .458 & 3.666 & .001 \\
\hline & FA & .472 & .162 & .365 & 2.917 & .005 \\
\hline
\end{tabular}

Dependen Variabel : KA

Dari tabel diatas dapat dilihat bahwa skeptisme professional (SP) diperoleh $t_{\text {hitung }}$ sebesar 3,666 dengan tingkat signifikan 0,001 $<0,05$ sesuai dengan ketentuan uji t, maka dapat disimpulkan $\mathrm{H}_{1}$ dalam uji $\mathrm{t}$ dapat diterima dan $\mathrm{H}_{0}$ ditolak. Skeptisme profesional berpengaruh signifikan terhadap kualitas audit sehingga dapat disimpulkan bhwa $\mathrm{H}_{1}$ dalam penelitian ini bahwa skeptime professional berpengaruh positif signifikan terhadap kualitas audit.

Fee audit (FA) diperoleh $t_{\text {hitung }}$ sebesar 2,917 dengan tingkat signifikan 0,005 $<0,05$ sesuai dengan ketentuan uji t, maka dapat disimpulkan $\mathrm{H}_{2}$ dalam uji t dapat diterima dan $\mathrm{H}_{0}$ ditolak. fee audit berpengaruh signifikan terhadap kualitas audit sehingga dapat disimpulkan bahwa $\mathrm{H}_{2}$ dalam penelitian ini bahwa fee audit berpengaruh positif signifikan terhadap kualitas audit.

\section{Koefisien Determinasi $\left(\mathbf{R}^{2}\right)$}

Koefisiaen determinasi menunjukan besarnya variasi nilai variabel dependen yang dijelaskan oleh semua variabel independen. Kemudian determinasi juga digunakan sebaga ukuran besarnya pengaruh semua variabel independen secara bersama-sama terhadap nilai variabel dependen. Hasil pengujian koefisien determinasi dapat dilihat pada tabel dibawah ini :

Tabel Uji Koefisien Determinasi $\left(\mathbf{R}^{2}\right)$

Model Summary

\begin{tabular}{|l|r|r|l|l|}
\hline Model & R & R Square & $\begin{array}{l}\text { Adjusted R } \\
\text { Square }\end{array}$ & $\begin{array}{l}\text { Std. Error of } \\
\text { The Estimate }\end{array}$ \\
\hline 1 & $.746^{\mathrm{a}}$ & .556 & .538 & 1986 \\
\hline
\end{tabular}

a.Predictors : (Constant), FA, SP 
Berdasarkan hasil output menujukkan bahwa nilai adjusted $\mathrm{R}$ square adalah 0,556, artinya skeptisme professional, fee audit dan kualitas audit sebesar 55,6\% dan sisanya 44,4\% dijelaskan oleh varibel lain yang tidak diteliti dalam penelitian ini.

\section{Pengaruh skeptisme professional dan fee audit terhadap kualitas audit}

Pengujian statistik pada uji $\mathrm{F}$ atau secara simultan menunjukkan bahwa skeptisme professional dan fee audit berpengaruh positif signifikan pada kualitas audit. Hal ini menunjukkan bahwa skeptisme professional sejalan dengan penelitian Dewa dan Wini (2016) yang menunjukkan bahwa skeptisme professional berpengaruh positif signifikan terhadap kualitas audit, dan variabel fee audit menunjukkan sejalan dengan penelitian I Gusti dan I Dewa (2017) yang menjelaskan bahwa fee audit berpengaruh positif signifikan terhadap kualitas audit.

\section{Pengaruh Skeptisme Profesional terhadap Kualitas Audit}

Pada pengujian uji t skeptisme professional berpengaruh positif signifikan terhadap kulitas audit. Ini menjelaskan bahwa seorang auditor memiliki sikap skeptisme profesional saat mengaudit laporan keuangan supaya meningkatkan hasil kualitas audit yang baik. Skeptisme professional terhadap kualitas audit berpengaruh positif signifikan, jadi bila seorang auditor menerapkan sikap skeptisme professional pada saat melaksanakan pengauditan laporan keuangan atau laporan audit akan menghasilkan tingkat kualitas audit yang baik.

Hasil penelitian ini didukung oleh teori Hery (2017:204) sesuai dengan standar audit, auditor harus mempertahankan sikap skeptisme professional sepanjang pelaksanaan audit. Dengan menyadari kemungkinan bahwa salah saji material yang disebabkan oleh kecurangan dapat terjadi, walaupun berdasarkan pengalaman penugasan masa lalu menunjukkan adanya kejujuran dan integritas dari manajemen klien, serta adanya pihak yang bertanggung jawab atas tata kelola. Untuk mempertahankan sikap skeptisme professional diperlukan pengajuan secara berkelanjutan (terus mempertanyakan) tentang apakah informasi dan bukti yang telah diperoleh memberi petunjuk bahwa salah saji material yang disebabkan oleh kecurangan mungkin terjadi. Hal ini meliputi pertimbangan terhadap keadilan informasi akan digunakan sebagai bukti audit, termasuk pengendaliannya. Sikap 
skeptisme profesional ini sangat penting ketika mempertimbangkan risiko salah saji material, terutama yang disebabkan oleh kecurangan.

\section{Pengaruh Fee Audit terhadap Kualitas Audit}

Pada pengujian uji $\mathrm{t}$ fee audit berpengaruh positif signifikan terhadap kulitas audit. Hal ini menjelaskan semakin tinggi fee audit maka semakin tinggi pula kualitas audit karena semakin luas prosedur udit yang dilakukan auditor dengan demkian hasil laporan keuangan yang dihasilkan dapat dipercaya.

Fee audit berpengaruh positif signifikan terhadap kualitas audit, jika semakin tinggi fee audit yang di terima oleh auditor maka semakin tinggi pula kualitas audit yang dihasilkannya, karena auditor dengan fee audit yang tinggi akan melakukan prosedur yang lebih luas sehingga kemungkina kejanggalan dalam laporan keuangan klien dapat terdeteksi dan akan menghasilkan audit yang berkualitas baik. Hal ini sesuai dengan beberapa penelitian yang menyatakan bahwa fee audit yang lebih tinggi akan merencanakan kualitas audit yang lebih tinggi juga apabila dibandingkan dengan fee audit yang rendah, karena apabila auditor mengalami tekanan harga dari klien dapat mempengaruhi kualitas audit yang semakin buruk. Perusahan-perusahaan yang besarlebih memilih membayar auditor dengan fee yang lebih tinggi dengan alasan karena mereka lebih mencari auditor yang dapat menghasilkan laporan audit yang berkualitas dan dapat meningkatkan kredibilitas laporan keuangan tahunan yang dapat bersaing diseluruh dunia, namun manajer yang tinggi apabila karakteristik perusahaan yang tidak bagus dan menyampaikan kepada publik.hasil penelitian ini sejalan dengan Zavara et al (2016) yang menunjukkan bahwa fee audit berpengaruh positif signifikan terhadap kualitas audit.

\section{Koefisien Determinasi}

Koefisien determinasi sebesar 0,556 menunjukan bahwa kualitas audit dapat dijelaskan dengan skeptisme profesional dan fee audit sebesar 55,6\% sedangkan sisanya 44,4\% dipengaruhi oleh variabel lain yang tidak diteliti. Artinya bahwa variabel skeptisme profesional dan fee audit hanya mengakibatkan atau menimbulkan adanya variabel kualitas audit sebesar 55,6\%. Sedangkan sisanya 
sebesar 44,4\% yang menyebabkan adanya atau meningkatnya kualitas audit diakibatkan oleh faktor lain seperti time budget pressure, independensi, audit tenure, etika auditor, kompetensi, profesionalisme auditor, dan lain sebagainya.

\section{SIMPULAN}

1. Hasil pengujian pada uji $\mathrm{F}$ atau secara simultan menunjukkan bahwa skeptisme profesional dan fee audit berpengaruh postitif signifikan pada kualitas audit. Hal ini menyatakan bahwa jika skeptisme profesional dan fee audit semakin tinggi maka semakin tinggi pula kualitas audit dimiliki. Sehingga kualitas audit yang dihasilkan semakin dapat dipertanggung jawabkan serta laporan keuangan yang telah diaudit diharapkan lebih berkualitas sehingga kepercayaan para pengguna laporan keuangan dan masyarakat pun meningkat.

2. Hasil pengujian pada uju $\mathrm{t}$ atau secara parsial skeptisme profesional terhadap kualitas audit ialah berpengaruh positif signifikan Ini menjelaskan bahwa seorang auditor memiliki sikap skeptisme profesional saat mengaudit laporan keuangan supaya meningkatkan hasil kualitas audit yang baik.

3. Hasil pengujian pada uji t atau secara parsial fee audit terhadap kualitas audit ialah berpengaruh positif signifikan Hal ini menjelaskan semakin tinggi fee audit maka semakin tinggi pula kualitas audit karena semakin luas prosedur audit yang dilakukan auditor dengan demikian hasil laporan keuangan yang dihasilkan dapat dipercaya.

4. Dari analisis data diperoleh nilai koefisien determinasi ( $R$ square) adalah sebesar $55,6 \%$. Artinya bahwa variabel skeptisme profesional dan fee audit hanya mengakibatkan atau menimbulkan adanya variabel kualitas audit sebesar 55,6\%. Sedangkan sisanya sebesar 44,4\% yang menyebabkan meningkatnya kualitas audit diakibatkan oleh faktor lain seperti time budget pressure, independensi, audit tenure, etika auditor, profesionalisme auditor dan lain sebagainya.

\section{DAFTAR PUSTAKA}

Dewa Ayu Wini Triarini, Ni Made Yeni Latrini. 2016. "Pengaruh Kompetensi, Skeptisme Profesional, Motivasi, Dan Disiplin Terhadap Kualitas Audit Kantor Inspektorat Kabupaten/Kota Di Bali" dalam E-Jurnal Akuntansi Universitas Udayana.14.2 (hlm. 1092-1119). 
Eveline, Hardi, Rheny. 2014. "Pengaruh Independensi, Kompetensi, Moral Reasoning Dan Skeptisisme Profesional Auditor Pemerintah Terhadap Kualitas Audit Laporan Keuangan Pemerintah Daerah" dalam JOM FEKON Vol. 1 No. 2.

Ghozali. 2001. Pengaruh Etos Kerja Disiplin dan Motifasi Kinerja Pegawai pada Dinas Perindustrian dan Perdagangan, Jakarta.

Hery. 2017. Auditing dan Asuransi Pemeriksaan Akuntansi Berbasis Standar Audit Internasional, Jakarta.

Hery. 2019. Auditing Dasar-Dasar Pemeriksaan, Jakarta.

Husein Umar. 2005. SDM Dalam Organisasi, Jakarta.

I Gusti Ayu Rahma Pramesti, I Dewa Nyoman Wiratmaja. 2017. " Pengaruh Fee Audit, Profesionalisme Pada Kualitas Audit Dengan Kepuasan Kerja Sebagai Pemediasi" dalam E-Jurnal Akuntansi Universitas Udayana Vol.18. (Halaman 616-645).

Lauw Tjun Tjun, Elyzabet Indrawati Marpaung dan Santy Setiawan 2012. "Pengaruh Kompetensi dan Independensi Auditor Terhadap Kualitas Audit" dalam Jurnal Akuntansi Vol.4 No.1 (Halaman 33-56).

Nihestita, Iin Rosini, Dani Rahman Hakim, Desi Kurniawati. 2018. "Pengaruh Integritas Dan Skeptisisme Professional Auditor Terhadap Kualitas Audit" dalam National Conference Of Creative Industry: Sustainable Tourism Industry For Economic Development (Halaman 915-925).

Nida Rinanda, Annisa Nurbaiti. 2018. "Pengaruh Audit Tenure, Fee Audit, Ukuran Kantor Akuntan Publik Dan Spesialisasi Auditor Terhadap Kualitas Audit" dalam e-Proceeding of Management : Vol.5, No.2.

Ni Luh Arlia Sugiarmini, Luh Kade Datrini. 2017. "Pengaruh Skeptisme Profesional, Independensi, Kompetensi, Etika, dan Role Stress Auditor Terhadap Kualitas Audit" dalam Jurnal KRISNA: Kumpulan Riset Akuntansi; Vol. 9 No.1 (Halaman 01-14).

Siregar. 2013. Statistik Nonparametik, Jakarta.

Syarhayuti. 2016. "Pengaruh Moral Reasoning, Skeptisme Professional Dan Kecerdasan Spiritual Terhadap Kualitas Audit Dengan Pengalaman Kerja Auditor Sebagai Variabel Moderating" dalam Akuntansi Peradaban : Vol. I No. 1. (Halaman 128147).

Susmiyanti. 2016. "Pengaruh Fee Audit, Time Budget Pressure, Dan Kompleksitas Tugas Terhadap Kualitas Audit Dengan Pengalaman Auditor Sebagai Variabel Moderating" dalam Jurnal Profita Edisi 7. (Halaman 1-16).

Sugiyono. 2017. Metode Penelitian Kuantitatif, Kualitatif Dan Kombinasi, Bandung.

Uma. 2006. Research Methods For Business, Jakarta.

Zavara Nur Chrisdinawidanty, Hiro Tugiman. 2016. "Pengaruh Etika Auditor Dan Fee Audit Terhadap Kualitas Audit" dalam e-Proceeding of Management : Vol.3, No.3. (Halaman 1-9). 